\title{
Being a Kenyan-Somali: A Security Threat or Neglected Citizen?
}

\author{
Peter K. Kirui \\ Lecturer, History and Government \\ Department of Humanities Education \\ University of Eldoret, Kenya.
}

\begin{abstract}
A Somalia government-backed militia, the Shifta, which called for the secession of Northern Frontier District in Kenya, was defeated by Kenyan forces and the Arusha Agreement on Ending Kenya-Somalia border hostilities was signed in 1967. While the Shifta was crushed, tension between Kenyan government and Somali community in Kenya continue and has been worsened by the securitization of Somalis in Kenya at the wake of Al Shabaab militia. Consequently, Somalis in Kenya complain of being treated as second class citizens. The current threat from Al Shabaab, a Somalia-based terrorist group has further worsened the tension between Kenyan government and Kenyan-Somalis whom the government accuses of allegedly secretly supporting the terrorist group. Using existing literature and observations through personal experiences as former humanitarian worker in Dadaab, this paper situates the dilemma of a being a Kenyan-Somali and the politics of belonging.
\end{abstract}

\section{1: Introduction}

Somalis of Kenyan nationality are probably the most "suspect" citizens in post-colonial Kenya. This mistrust and suspicious perception towards Kenyan Somalis started immediately after independence in 1963 with the Shifta war ${ }^{1}$, a war in Northern Frontier District (NFD) aimed at secession (Whittaker, 2012). NFD is also called Northeastern Province (NEP) currently comprising of Wajir, Mandera and Garissa counties. Ever since, the sovereignty, hegemony and monopoly of violence of the Kenyan state has been challenged in the NFD. While territory control was the challenge of many modern states in the developing world (Leftwitch, 2011), the NFD is the only region in Kenya to offer such a formidable challenge. Even though the Shifta war ended with the signing of Arusha Agreement ${ }^{2}$ on Ending Kenya-Somalia border hostilities in 1967, Somalis in Kenya struggle for acceptance to belong to the Kenyan state with the rest of the population viewing them as "foreigners". In colonial Kenya, the British neglected NFD and administered it as separate entity within Kenya because of insecurity hence paving way for its post-colonial economic and political marginalization (Whittaker, 2012). Somalis being a nomadic pastoral community, the Kenyan state found it even more difficult to control them. While pastoral communities like Maasai existed elsewhere in Kenya, Somalis of NFD were not culturally and territorially integrated within the Kenyan state (Kituyi, 1990).

\subsection{Problem statement}

Kenya has in the recent past faced a series of terrorist attacks from Somalia-based terrorist militia, $\mathrm{Al} \mathrm{Shabaab}{ }^{3}$, with networks in Kenya. In an attempt to dismantle the terrorist group, mainly comprised of ethnic Somalis, the Kenyan government finds itself unable to penetrate the Somali community so as to weed out the militia. Part of the reason of failure of the state to penetrate ethnic Somalis may be attributed to the questioned "belonging" of Somalis to the Kenyan state. This notion of belonging was raised because of post-independence attempts by ethnic Somalis in northeastern Kenya to secede (Shifta war) and their pastoralist lifestyle often portraying them as immigrants (Scharrer, 2018). This culminated in marginalization on the basis of autochthony and the subsequent ambiguous citizenship of Somalis often perceived as aliens and strangers by the Kenyan government. Autochthony is the notion of localizing belonging (Geschiere, 2009). It is the idea that belonging is rooted in the soil one is born into (Geschiere \& Jackson, 2006).

\footnotetext{
${ }^{1}$ Shifta is a Somali word for "bandit or rebel". The Shifta War (1963-1967) was a secessionist war fought in NFD between Kenyan security forces and Shifta rebels supported by government of Somalia.

${ }^{2}$ A peace Agreement signed after a meeting chaired by then President Kenneth Kaunda of Zambia at Arusha in Tanzania on 28 October 1967. See Keesing's Record of World Events (formerly Keesing's Contemporary Archives), Volume 13, November, 1967 Kenya, Somalia, Ethiopia, Kenyan, Somali, Ethiopian, Page 22386. Website: http://web.stanford.edu/group/tomzgroup/pmwiki/uploads/1378-1967-11-KS-a-RRW.pdf

${ }^{3} \mathrm{Al}$ Shabaab, A Somali word for "the Youth" is an Islamic terrorist group based in Somalia and affiliated to Al-Qaeda 
This categorization seem to have entrenched the view that Kenyan Somalis belong to a different political community that differs fundamentally from that of the rest of Kenyan community hence unmaking them as not part of the nation (Straus, 2015).

Consequently, the Kenyan government finds itself using brutal force against ethnic Somalis in an attempt to collect intelligence about Al Shabaab terror militia hence further pushing the Somali community towards mistrusting the state. This has made it easy for the Al Shabaab militia to hide among Kenyan-Somali communities as it unleashes guerrilla warfare on security agents and civilians. Unless the Kenyan-Somali community wins the trust of the Kenyan (state) government, the rift between Kenyan-Somalis and the Kenyan government will continue to grow while Al Shabaab take advantage of the adversarial relationship to unleash more terror and destabilize the Kenyan state.

\subsection{Objectives}

This paper first attempts to explain the developments of the Shifta War as the basis of ambiguous citizenship of the Kenyan-Somalis. Secondly, it explores why integration of Somalis to the Kenyan population was and still problematic and the different narratives, including a version of autochthony, that questioned the extent of their 'Kenyan-ness'. Thirdly, it analyzes securitization of Kenyan-Somalis as a scapegoat to the threat from Somalia-based Al Shabaab and as an extension of this othering narrative. Finally, it explores the contribution of Somalis in state building as basis for a more receptive Kenya to Kenyan-Somalis, and as prerequisite to taming Al Shabaab terror threats and establishing a truly united Kenya.

\subsection{Reflection on methodology}

The paper is based on an analysis of secondary literature. Some reports from select humanitarian organizations are also reviewed. Personal experiences as Kenyan who has worked with International Non-Governmental Organization (INGO) in the Dadaab refugee camp in the NFD for three years were helpful in putting issues raised into perspective. My earlier field research on Somali refugees in 2012 was also helpful in informing this policy paper.

\section{2: Literature Review}

\subsection{Autochthony, historical injustices and questioned citizenship of Kenyan Somalis}

Autochthonous is a term "reserved for people who are dominant in a given area but fear future marginalization" (Gausset, Kenrick \& Gibb, 2011, p.135). As will be discussed later, while Kenyan-Somalis origin of NFD is undisputed, their being born there has not given them the full rights enjoyed by the rest of Kenyans and are still viewed as outsiders. As rightly put by Scharrer, "the question for Kenyan Somalis is not, therefore, if they belong to Kenya, but how"(Scharrer, 2018, p.494). While citizens ideally should enjoy equal treatment and rights, in practice citizens can still be framed as outsiders and be seen as not fully belonging to the nation-state(Scharrer, 2018). This is actually the case for the Kenyan Somalis.

Autochthony discourse has received considerable attention among scholars regarding the politics of belonging. Geschiere and Jackson (2006) for instance argue that autochthony and similar notions of belonging are not special to Africa as they are spread all over the world. Autochthony indeed easily bridges the gap between the South and North and is common in Canada, Pacific, Netherlands, Flanders and many other parts of Europe (Geschiere \& Jackson, 2006; Ceuppens \& Geschiere, 2005). The common feature of all autochthony discourses is that it is an attempt by autochthons, the supposed "sons and daughters of the soil" to exclude the allochthons, the supposed perceived "foreigners or strangers" (Nyamnjoh \& Geschiere, 2000).

However, autochthony discourses in Europe differ from those in Africa, in Europe it is more about limiting the benefits of the welfare state to those said to really belong and not necessarily fear of being dominated or outvoted by "foreigners" (Ceuppens \& Geschiere, 2005). Although Ceuppens and Geschiere (2005) argue that ideas of citizenship in Africa have been overshadowed by those of autochthony, autochthony discourse only matters regarding what Scharrer (2018, p.495 ) terms "who can vote where" but does not affect the general idea of citizenship. Perhaps because Africa has relatively young modern states, "outsiders" may still be perceived as potential threat to the state.

In Kenya, the perception that Somalis are allochthons seems to be motivated by a number of reasons. First, the fear by the Kenyan state that although the Shifta War was won, threats by sympathisers of secessionist ideals could still be a reality. This narrative (of seeing Somalis as threat to the state), though not publicly proclaimed by state security officials informs their attitude considering the way security threats in North-eastern Kenya or involving KenyanSomalis are always perceived as a national security threat (Kirui \& Mwaruvie, 2012). This narrative portrays ethnic Somalis as enemies of the state. Because the Kenya-Somalia border is long and porous, it is virtually impossible to monitor or distinguish Somalis from Somalia and those from Kenya (Kirui \& Mwaruvie, 2012). 
Secondly, besides the Shifta War, the Wagalla Massacre ${ }^{4}$ of 1984 where an estimated 1000-5000 Somalis were killed by state security agents demonstrates the sheer brutality of the state against Kenyan-Somalis at the time. The Wagalla Massacre followed a botched disarmament operation aimed at disarming the pastoral Somali ethnic community but ended up with a massacre of civilians at the Wagalla airstrip (Sheikh, 2007). The state, often seem to resort to collective punishments of ethnic Somalis after failing to penetrate and manage them. These two experiences seem to have been the basis of ethnic Somalis exclusion in state building.

The affiliation of Somalis Al Shabaab to Al Qaeda means that Al Shabaab's attack on Kenya could easily be termed a global threat in the so called "global war on terror"(Jaji, 2014). Secondly, notable racial, cultural and religious difference between Somalis and the rest of Kenyans seemed to have contributed in their exclusion as outsiders. The fact that Somalis are highly homogenous with over $99 \%^{5}$ of them Muslims meant that exclusion or separation was almost natural from the rest of Kenyan Christian majority ${ }^{6}$. Because terror groups like Al Shabaab claim allegiance to Islam, the perception created (often exaggerated) is that of seeing Somalis as "war happy" hence the perception that they are a threat. This view especially gained prominence after the USA $11^{\text {th }}$ September 2001 terror attack and has since made the Muslim identity politicized (Kimball, 2002).The Kenyan-Somali, like other Muslims globally, are hence victimized (Castles, 2003; Hughes, 2007; Juma \& Kagwanja, 2003; Muller, 2004) and even those seeking asylum may sometimes be rejected on this basis even if they are not directly linked to terrorism (Van Selm, 2003).

Interestingly, for the case of Kenyan-Somalis, their being natives of the NFD in Kenya is not being questioned, whether that actually qualifies them as "true" Kenyans is one that is questioned. Since independence, NFD has been governed under emergency regulations which were lifted in 1991(Menkhaus, 2015). The NFD was therefore separated from the rest of Kenya and ethnic Somalis were expected to register so as to verify their belonging hence establishing their position as "ambiguous citizens" (Whittaker, 2014). This has led to exclusion of both the NFD region and its people (Kenya Human Rights Commission, 2009). Consequently, being ethnic Somali bears with it the burden of proving and justifying your Kenyan-ness. This exclusion and victimization of Somalis seem to be worsened by the fact that ethnic Somalis are physically distinct from the rest of Kenyans making them easy targets of those intending to question their citizenship.

Perhaps nothing demonstrates this better than my own experience in 2009, a "true" Kenyan on a work assignment at the NFD currently in Garissa County:

A relatively fresh graduate, I was employed by an international humanitarian organization to work as an Assistant Education officer at the then world's largest refugee camp, Dadaab refugee camps in North eastern Kenya. A flight to the arid sun-scorched Dadaab camps takes one hour from Nairobi, Kenya's capital. After six weeks in the non-family duty station (partly because of the volatile security situation), it was time to take a break, this time the near $500 \mathrm{~km}$ journey to Nairobi was by road. After close to three hours drive in the sandy dusty road, with several security checks, we arrive at Garissa town, the beginning of the bitumen road to Nairobi. However, before we cross the Tana River, so that we "enter" the "true" Kenya, everybody disembarks from the vehicle with their national identity card or passport for verification before being allowed to board and continue the journey. Somali refugee from the camps must have their alien cards and UNHCR mandate letters stating the reason for their travel outside the refugee camps. This is quite similar to any international border crossing point, only that this is within Kenya. Muslim women with hijab-covered faces are sometimes forced to remove, it is a thorough scrutiny. As I handed my identity card to the police man for verification, he ushers me to board the vehicle without looking at it. Why not verify my identity card? My mind raced. I quickly understood the reason, my distinct physical features qualified me as a "son of the soil", my appearance was proof of "true" citizen, I needed no documentary proof. I empathised with majority of Kenyan-Somalis who have to live as aliens in their own country. ${ }^{7}$

Because of such experiences as described above in my journey to Nairobi, Kenyan-Somalis have often complained that they are discriminated and taken as lesser Kenyans especially by state security apparatus (Burbidge, 2015).The inability of Kenyan state security apparatus to distinguish between Somali Islamists (blamed for past rebellion and currently terrorism) and Kenyan Somalis points to a missed opportunity in national integration (Burbidge, 2015).

This perception of the state (GoK) regarding Somalis seems to inform that of the general population who have little contact with Somalis in the NFD.

\footnotetext{
${ }^{4}$ Truth, Justice and Reconciliation Commission, Report 2 A, 221-367

${ }^{5}$ https://rlp.hds.harvard.edu/faq/islam-somalia

${ }^{6}$ Christians comprise about $85 \%$ of Kenyan population according to census of 2009 by Kenya National Bureau of Statistics. See https://www.knbs.or.ke/religious-affiliation/

${ }^{7}$ Personal experience of this writer, recollecting the memories of Dadaab-Nairobi journey in August, 2009 
Apart from state security agents, civil servants, INGO staff and a few businessmen, very few non-Somali Kenyans have interacted with Somalis. Indeed, I had to severally clarify to my friends and relatives that Dadaab, where I worked then, was in Kenya and not in Somalia as many of them had thought. In many instances, many told me that the name "Dadaab" did not sound Kenyan.

The exclusion of the NFD region and its people as not being part of "true" Kenya explains why there is little interaction between ethnic Somalis and other non-Somali Kenyans. Even in urban areas, ethnic Somalis prefer to stay together in estates and communes. This explains why an estate, like Eastleigh ${ }^{8}$ in Nairobi, is often targeted by anti-terrorism police and immigration officials when cracking down on undocumented illegal immigrants mostly ethnic Somalis. The fact that ethnic Somalis prefer residing in specific areas even in a city like Nairobi suggests their lack of trust, connection or belonging with the rest of Kenyan population.

This could partly explain why ethnic Somalis have kept their identity intact and have not sought to emulate the rest of Kenyan population. They have maintained Islam, their pastoralist culture and avoid intermarriage even with nonSomali Kenyan Muslims. This closed conservative nature seem to have isolated them further but my experience with them shows that they are indeed proud of their identity. Indeed being amidst the Kenyan-Somalis as a non-Somali Kenyan attracts a similar (if not severe) exclusion and discrimination. Perhaps this is their way of "revenge" for the supposedly fair treatment that other non-Somali Kenyans receive from state agents. In Kenyan-Somali circles, nonSomali Kenyans are called madow, a pejorative term translated as "black" ostensibly in ridicule of the black colour and hair. This is however historical and even played out at the differentiated citizen rights and classification in colonial period. In fact, historically, Somalis in colonial Kenya wanted this distinction acknowledged and wanted to be "treated as "Asians", set apart from the "African" population' (Scharrer, 2018, p. 496). In a way therefore, the demand to be classified as Asians in colonial Kenya could have set the post-colonial attempts at integration with the rest of the Kenyan African population futile.

\section{Somalis as "Outsiders" in Kenya: Problems and prospects}

\subsubsection{Integrating Kenyan Somalis in statebuilding: Attempts at integration}

The government of Kenya attempted to contain the Shifta rebels through a forced villagization program where they were expected to settle in designated villages under a security guard (Whittaker, 2012).This attempts at sedentarization (Scott, 1998 ) may be seen as an attempt of the Kenyan state to simplify its function and hopefully make the Somali legible and easy to control. Like many forced programmes, it failed and by end of 1967 only half of the population had been villagized (Whittaker, 2012). Given that Somalis were nomadic pastoralists and communally owned land, they resisted sedentarization. Luckily, the improvement of communication technology, infrastructure, etc has increasingly globalized even the most of remote villages rendering extreme programmes like villagization untenable and unnecessary. Through these infrastructures, like say mobile phones, the state can now penetrate and interact with society even in remote North-eastern Kenya. To do this however, the Kenyan state has to change its narratives about Somalis as "strangers" so as to win their trust and support.

\subsubsection{Kenyan-Somalis and Somali refugees as scapegoats}

Since mid October 2011 when Kenya Defence Forces (KDF) entered Somalia in hot pursuit of Al Shabaab, Somalis in Kenya (refugees and citizens) have been indirectly blamed by Kenyan state accusing them of being sympathizers of $\mathrm{Al}$ Shabaab. As Al Shabaab intensified its retaliatory guerrilla terror attacks on Kenyan civilians and security agents, the GoK conducted a security crackdown dubbed "Usalama Watch" aimed at weeding out aliens and illegal immigrants. The narrative was that "foreigners" and illegal immigrants were behind the terror attacks and that they were to be rounded-up and deported. This narrative, however, lacks substance as no one was successfully convicted for links with terrorism as a result of the security operation. While the intention may have been noble, the Usalama Watch ended up almost indiscriminately targeting the Somali community prompting human rights groups and organizations to raise their concerns and protests. According to one Amnesty International (AI) report at the time, it observed that "The Somali community in Kenya have become scapegoats in Kenya's counter-terror operation known as 'Usalama Watch" ${ }^{10}$ (Amnesty International, 2014, p.4). The Human Rights Watch (HRW) in its World Report of 2015 also noted that "As in previous similar operations, Kenyan police arbitrarily detained several thousand people and used excessive force, raiding homes, extorting residents, and physically abusing ethnic Somalis" (HRW, World Report, 2015, p.9).

\footnotetext{
${ }^{8}$ An estate east of Nairobi occupied mostly by Somalis. Most Kenyans in urban areas do not reside along ethnic lines as is the case for ethnic Somalis

${ }^{9}$ Usalama is a Swahili word for peace and security. "Usalama Watch" was a security operation aimed at "restoring security".

10 Amnesty International report of 2014 titled "Somalis are scapegoats in Kenya's counter-terror crackdown". https://www.amnesty.org/download/Documents/4000/afr520032014en.pdf
} 
Even the state's agency Kenya National Commission on Human Rights (KNCHR) protested about the human rights violations and forced disappearances of suspects especially those of ethnic Somalis and of Muslim faith ${ }^{11}$.

This harsh treatment stems from the fact that GoK perceives Somalis and Muslims as a security threat internally and externally from spillovers from conflict ridden Somalia (Lind, Mutahi \& Oosterom, 2017). To show the extent of GoK's adverse attitude to Somalis in Kenya, an Assistant Minister of Internal Security had earlier described insecurity in Kenya as "big animal with its head in Eastleigh, Nairobi and its tail in Somalia"12. Eastleigh is an estate eastwards of Nairobi with majority Kenyan-Somalis whose relatives and clan members spread across both NFD and Somalia.

Somali refugees have not been spared either. GoK has on numerous occasions blamed Somali refugees in Dadaab refugee camps as providing a haven for terrorists. While no Somali refugees have been convicted with terrorism, the GoK maintains that the Dadaab camps have acted as training grounds and hideouts for refugees. However, the Global War on Terror, according to Jaji (2013, p.355) may have contributed in depicting Somali refugees as "local and regional epitome of contemporary global terrorism". An Independent Police Oversight Authority (IPOA) report ${ }^{13}$, a state agency admitted that it was monitoring the Usalama Watch crackdown and that refugees had been returned to the refugee camps and others deported.

The GoK has in many occasions attempted to close down Dadaab refugee camps citing national security concerns. This has, however, not been implemented as the High Court has severally stopped this government efforts arguing it goes against rights of Somali refugees and does not respect human rights. In one search ruling, Justice Mativo observed that "The government's decision specifically targeting Somali refugees is an act of group persecution, illegal discriminatory and therefore unconstitutional" ${ }^{14}$. Pressure from the international community and humanitarian organizations has also help put pressure on GoK to rescind.

\subsubsection{Challenging autochthony, ambiguous citizenship of Somalis: prospective inclusive politics}

Like many ethnic minorities that face threats or some sort of discrimination, Somalis in Kenya have navigated through their challenges and become useful members of the society. It is in the success stories of Kenyan-Somalis that the narrative that sees them as outsiders and threat to security can be challenged and reconstructed. Indeed Scharrer (2018, p.502) while writing on ambiguous citizenship of Kenyan Somalis has noted that "Kenyan Somalis have become a stronger part of the Kenyan political sphere, as well as of the Kenyan economy, yet they are still marginalized". The increasing influence of ethnic Somalis in business and politics, however, does not seem to help them shed off the "outsider" tag. As will be demonstrated below under business and politics, it appears that even the most noble and positive contribution of ethnic Somalis to Kenyan state will ultimately be "demonized" hence perceived as threat and seen as attempts to undermine the state. Somali increasing influence could easily be perceived as attempts to ultimately "take over Kenya" (Scharrer, 2018, p.498). While business and politics provide a good opportunity for Somalis to assert their authority as Kenyan citizens, it is equally a platform through which their belonging is questioned even more intensely.

\subsubsection{Somali influence in business}

Somalis in Kenya are known for their business acumen. Eastleigh, an estate in Nairobi dominated by Somalis is as of 2018 the second ${ }^{15}$ business hub in Nairobi after Nairobi's Central Business District (CBD). Praising Eastleigh's economic prowess, Nairobi Governor Mike Sonko recently observed that Eastleigh had overtaken Westlands to become Nairobi's second business hub after Nairobi CBD. ${ }^{16}$

\footnotetext{
${ }^{11}$ Kenya National Commission on Human Rights, 'The Error of Fighting Terror with Terror' September 2015. http://www.knchr.org/Portals/0/CivilAndPoliticalReports/Final\%20Disappearances\%20report\%20pdf.pdf

${ }^{12}$ The Standard, 'Minister Says Eastleigh the next Target in the Hunt for Al-Shabaab Militants', October 20, 2011. See also BBC "Kenya to target al-Shabab sympathizers in Nairobi", 20 ${ }^{\text {th }}$ Oct, 2011. https://www.bbc.com/news/world-africa15384331

${ }^{13} \mathrm{https}: / / \mathrm{www}$. google.com/url?sa=t\&rct=j\&q=\&esrc=s\&source=web\&cd=1\&ved=2ahUKEwiupYP19bgAhXBwKQKHQJQCxwQFjAAegQIBBAC\&url=https\%3A\%2F\%2Fwww.rckkenya.org\%2Fv2\%2F\%3Fmedia_dl\%3 D820\&usg=AOvVaw1cTRTj7QWS07G0QHiygSZy

14 BBC, "Kenya closure of Dadaab refugee camp blocked by High Court", 9th February, 2017. https://www.bbc.com/news/world-africa-38917681

${ }^{15}$ The Standard. Eastleigh: From lonely dusty estate to business epicenter. https://www.standardmedia.co.ke/article /2001288086/ eastleigh-from-segregation-icon-to-business-leader

${ }^{16}$ The Standard. Eastleigh: From lonely dusty estate to business epicenter. https://www.standardmedia.co.ke/article/ 2001288086/ eastleigh-from-segregation-icon-to-business-leader
} 
While the exact amount that Eastleigh contributes to the economy is unknown, estimates indicates that up to $30 \%$ of Nairobi County taxes are collected from Eastleigh (Kabale, 2018). This success may partly be attributed to Somali refugees who receive remittances from oversees relatives (Lindley, 2007) making it easy to access financial capital and other business. Inspite of Eastleigh's economic growth, it has been linked (though often exaggerated) with terrorism and piracy (Carrier, 2017).It has been neglected and has suffered from poor infrastructure and high crime rate (Lindley, 2007). Estleigh's economic prospects increased since the early 1990's. Indeed competition for rental and business premises in Eastleigh intensified after the influx of Somali refugees in1991further pushing the rents from the reach of many Kenyans (Hyndman, 2000). Such business competition, though noble, may attract jealousy that portrays Somalis as domination. Some attributed the Usalama Watch security crackdown on ethnic Somalis as ethnic profiling of Somalis because of their prominence in business and politics (Abubakar, 2014).

While GoK is justified to ensure security of its people, this can be achieved without antagonizing the Somali community through blanket accusations. Because the business community in Eastleigh is interested in peace for business, the GoK can easily find allies who are willing to expose trouble makers to the state. Although business success is likely to evoke envy from non-Somali Kenyans, it puts ethnic Somalis at an influential position to call for equal treatment before the law enforcement agencies.

\subsubsection{Somali growing influence in politics/public service}

While there has been a tremendous increase in population of ethnic Somalis (numbers signalling political strength), there has been a corresponding othering of ethnic Somalis in equal measure. For example, the census of the ethnic Somalis in NFD of 1999 and 2009 were hotly disputed as inflated because it also forms the basis of division of national revenue to various regions. Ethnic Somali increase in population from approximately 800,000 to 2,400,000 in the 1999 and 2009 census respectively became a political concern (Scharrer, 2018). Even though the 2.4 million numbers was later nullified and "adjusted" numbers published, they are still considered controversial (Leftie \& Otieno, 2010). Census, like in many parts of the world, seems to be a good instrument in "politics of recognition" (Balaton-Chrimes, 2011, p.215).

The role of ethnic Somalis in politics gained momentum from 2013 elections for two reasons. First is the requirement of the Kenya New Constitution (2010) that requires one to garner more than $50 \%$ of votes cast to be declared president. Aware of their neglected past, and the fact that Somalis may not field a presidential candidate, political parties wooed Somali voters with promise of strategic government jobs once in power. The growing influence of Kenyan Somalis and their relatively good performance in public service, though gaining momentum, attracts similar fears of being ruled by "aliens". The newly appointed Director of Public Prosecutions (DPP) Nordin Haji, Cabinet Secretary Amina Mohamed and Hon. Aden Duale, leader of Majority party in the National Assembly are among senior government officials that have brought the Somali community at the forefront in national politics. Being a Somali, Aden Duale was at one point put to task to name those behind terrorism (Shiundu, 2015) as a Member of Parliament (MP) of Dujis, a constituency in Garrisa where Alshabaab had selectively attacked students of Garrisa University ${ }^{17}$ killing non-Muslim students. This profiling even of senior politicians of ethnic Somali is not new in Kenya. In 1993 for example, a Somali MP (together with other Somalis) were barred by a Principal Immigration officer from entering a passport-issuing office. The justification was that"A Somali, whether from Somalia or from Kenya, is a Somali because mtoto wa nyoka ni nyoka [The child of a snake is a snake].”(Hansard, Parliamentary Debates, July 21, 1993, p. 1524.)

While the increased role of ethnic Somalis in national politics may be a mere political bait to attract votes from NFD that is considered a swing votes zone (Scharrer, 2018), it offers an opportunity for ethnic Somalis to hopefully shed off the "foreigner" tag. Albeit their positions risks being taken as attempts to control and take over, it provides an opportunity for national integration through advocating for Somali rights as citizens. As indicated however, the desire to belong is almost impossible to achieve as demonstrated by the case of Immigration Officer who reminds the MP of his "foreign-ness" despite being a member of the National Assembly. Senior political positions held by Somalis will nevertheless, hopefully, help shape inclusive government policy towards ethnic Somalis.

\subsubsection{Inclusion and acceptance of Kenyan-Somalis: A key ingredient in fight against Al Shabaab}

The perception that Somalis are considered as outsiders by Kenyan state has come to be the greatest hurdle of GoK in the fight against Al Shabaab cells in Kenya. Although Alshabaab do not directly feature on the discourses of autochthony, where ethnic Somalis are perceived as outsiders, the fact that their ultimate aim is Islamization to form a caliphate ${ }^{18}$ in Somalia sucks in the Somalis in Kenya. Calls by Al Shabaab on their "Somali Muslim brothers" seem to indirectly consolidate the perception that Kenya is only a secondary home for ethnic Somalis.

\footnotetext{
${ }^{17}$ https://www.refworld.org/docid/5be9430a13.html

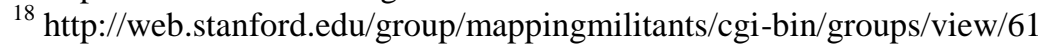


It seems to imply that they are not "rooted" (Geschiere \& Jackson, 2006) in Kenyan soil and have their motherland in Somalia. Because the aim of Al Shabaab is to incite the ethnic Somalis (Muslims) against the Kenyan state, the fact that Somalis are viewed as "outsiders" in Kenya serves Al Shabaab's interest of separation and rebellion instead of national unity. Indeed, Geschiere (2011, p.343) has warned that depending on context "autochthony can become a dangerous rival to national citizenship, drastically undermining earlier ideals of national unity and the equality of all national citizens".

National unity requires a high level of trust by all citizens to the state. This is not currently the case between ethnic Somalis and Kenya's security apparatus. The state has failed to win the trust of Kenyan Somali citizens and refugees and this has hampered their efforts to fight Al Shabaab terror cells in Kenya. Because Al Shabaab does not have the military power to fight a conventional war with KDF or Kenya police, it utilizes the weak link between Somali community and security apparatus to plan and execute guerrilla attacks. The feeling by ethnic Somalis in Kenya that their being Kenyan does not guarantee them the desire for belonging may make them vulnerable to Al Shabaab activities or simply sympathize with them. National integration of Somalis in Kenya is therefore paramount in building the sense of belonging and patriotism which help ward off attempts of destabilization by various factions within Kenya and in Somalia.

\section{Conclusion}

\subsection{Conclusion.}

This paper has traced the historical exclusion of Somalis on the basis of autochthony and the Shifta War that planted seeds of mistrust with the Kenyan state. On this basis, Kenyan Somalis are discriminated and their citizenship "questioned". The state's securitization of ethnic Somalis, both Kenyans and refugees, has led to many human rights abuses and has further intensified the mistrust. Consequently, Somali-based Al Shabaab terror cells in Kenya have taken advantage of the mistrust between Somalis and Kenya's security apparatus to plan and execute guerrilla attacks undetected. Nevertheless, Somalis have positively greatly contributed to Kenya's economy, its politics and public service. They are engaged in statebuilding and are increasingly rising to influential positions in government. While these influences in business and politics is laudable, it risks being perceived as attempts by ethnic Somalis to dominate and eventually "take over". These platforms in influential business and political strategic positions should be seen as platforms to challenge the view of Somalis as "outsiders" and not necessarily a remedy by itself. While perceptions of belonging based on autochthony are not necessarily problematic, the associated security and rebellion risks associated with it in the case of Kenya and Somalis is reason for concern. The fact that armed militia, like Al Shabaab, ride on questioned belonging of Somalis in Kenya to plan and launch attacks is problematic.

\subsection{Recommendations}

Given that ethnic Somalis have been discriminated and unfairly targeted as "outsiders", they have felt neglected and excluded in the nation building. Due to this mistrust, the state finds it difficult to maintain law and order among Somali populations hence use brutal force as last resort. Among the raft of recommendations that may help improve the relationship between ethnic Somalis and the GoK are:

1. A sustained new narrative that is founded on inclusive politics where ethnic Somalis are reconstructed as inherent members of the Kenyan community. Though controversial, the contribution of Somalis in business and politics could offer a good platform of portraying them as useful members of society.

2. A sustained GoK led state efforts to de-securitize the Somalis in exchange for a cooperative, mutual relationship based on the rule of law. This will make Somalis partners and allies with GoK in the fight against rebel elements among them like the Al Shabaab. Improved Somali-GoK relations may improve national integration.

3. Implement the Truth Justice and Reconciliation Commission report that, among others, looked into historical injustices of the state against the Somali population with a view of taking responsibility. Although this may not address the view that Somalis could still be considered as outsiders, it will help rebuild trust and improve on Somali-GoK relations and may enhance prospects of greater national integration.

Peter Kirui is a lecturer at the department of Humanities Education, University of Eldoret, Kenya. He is due to graduate with Phd in Conflict Transformation and Peace Studies from University of KwaZulu Natal, South Africa. He is currently a Master VLIR-UOS Scholar at the Institute of Development Policy-IOB, University of Antwerp, Belgium. 


\section{References}

Abubakar, H. M. (2014). Kenya's Somalis: Caught between power and profiling. African Arguments . https://africanarguments.org/2014/06/23/kenyas-somalis-caught-between-power-and-profiling-by-hassan-mabukar/

Achuka, V. (2018). Eastleigh: From a lonely dusty estate to a business epicentre .The Standardard, 15th July, 2018.Retrieved from https://www.standardmedia.co.ke/article/2001288086/eastleigh-from-segregation-iconto-business-leader

Burbidge, D. (2015). The Kenyan state's fear of Somali identity. Conflict Trends, 3. African Centre for the Constructive Resolution of Disputes (ACCORD). https://www.accord.org.za/conflict-trends/the-kenyan-statesfear-of-somali-identity/

Carrier, N. (2017). Little Mogadisshu: Eastleigh, Nairobi's global Somali hub. Oxford: Oxford University Press.

Castles, S. (2003) .Towards a sociology of forced migration and social transformation.

Sociology, 37(1), 13-34.

Ceuppens, B. \& Geschiere, P. (2005). Autochthony: Local or global? New modes in the struggle over citizenship and belonging in Africa and Europe. Annual Review of Anthropology, 34(1), 385-407.

Gausset, Q., Kenrick, J., \& Gibb, R. (2011). Indigeneity and autochthony: a couple of false twins? Social Anthropology/Anthropologie Sociale, 19(2), 135-142.

Geschiere, P. (2011). Autochthony, citizenship, and exclusion paradoxes in the politics of belonging in Africa and Europe. Indiana Journal of Global Legal Studies, 18(1), 321-339.

Geschiere, P. (2009). The perils of belonging: Autochthony, citizenship and exclusion in Africa and Europe. Chicago and London: University Press of Chicago.

Geschiere, P. \& Jackson, S. (2006). Autochthony and the crisis of citizenship: Democratization, decentralization, and the politics of belonging. African Studies Review, 49(2), 1-7.

Geschiere, P. \& Nyamnjoh, F. (2000). Capitalism and autochthony: The seesaw of mobility and belonging. Public Culture, 12(2), 423-452.

Harvard Divinity School. Islam in Somalia. Retrieved from https://rlp.hds.harvard.edu/faq/islam-somalia

Hughes, G. (2007). Community cohesion, asylum seeking and the question of the 'stranger'.Cultural Studies, 21(6): 931-951.

Hyndman, J. (2000). Managing displacement: Refugees and the Politics of Humanitarianism. Minneapolis: University of Minnesota Press.

Jaji, R. (2014).Religious and ethnic politics in refugee hosting: Somalis in Nairobi, Kenya. Ethnicities, 14(5), 634-649.

Jaji, R. (2013). Somali Asylum Seekers and Refoulement at the Kenya - Somalia Border. Journal of Borderlands Studies, 28(3), 355-368.

Juma , M.K. and Kagwanja, P.M. (2003). Securing refugee from terror refugee protection in East Africa after September 11. In N. Steiner; M. Gibney and G. Loescher (Eds.), Problems of Protection: The UNHCR, Refugees, and Human Rights(pp.225-236). New York, NY: Routledge.

Kabale, N. (2018). Nairobi's Eastleigh markets itself as a retail tourism hub. The Standard, 8th April, 2018. https://www.standardmedia.co.ke/article/2001276122/eastleigh-now-wants-to-be-a-tourist-attraction

Kenya Human Rights Commission. (2008). Foreigners at home: The dilemma of citizenship in Northern Kenya. Retrieved from https://www.khrc.or.ke/mobile-publications/equality-and-anti-discrimination/66-foreigners-athome-the-dilemma-of-citizenship-in-northern-kenya/file.html

Kenya National Assembly. (1993). Hansard, Parliamentary Debates, July 21, 1993, p. 1524.

Kimball, C. (2002). When religion becomes evil. New York, NY: HarperCollins Books.

Kirui, P. \& Mwaruvie, J. (2012). The dilemma of hosting refugees: A focus on the insecurity in North-eastern Kenya. International Journal of Business and Social Science, 3(8), 161-171.

Kituyi, M. (1990) Becoming Kenyans: Socio-Economic Transformation of the Pastoral Maasai, Nairobi: Acts Press.

Leftie, P. \& Otieno, J. (2010). How North Eastern Figures Went Wrong. Daily Nation, 1 September 2010. Retrieved http://www.nation.co.ke/news/How-North-Eastern-figures-went-wrong-/1056-1001530-1d3tow/index.html.

Leftwich, A. (2011). Theorizing the State, in P. Burnell (Ed.), Politics in the Developing World, Oxford: Oxford University Press.

Lind, J., Mutahi, P., \& Oosterom, M. (2017). 'Killing a mosquito with a hammer': Al-Shabaab violence and state security responses in Kenya. Peacebuilding, 5(2), 118-135.

Lindley, A. (2007). Protracted displacement and remittances: the view from Eastleigh, Nairobi. New issues in refugee research, Research Paper No. 143. 
Menkhaus, K. (2015). Conflict Assessment: Northern Kenya and Somaliland. Danish Demining Group, 2015. http://dx.doi.org/10.2139/ssrn.2589109.

Muller, B. (2004). Globalization, security, paradox: towards a refugee biopolitics. Refuge, 19(5), 49-57.Scharrer, T. (2018). "Ambiguous citizens": Kenyan Somalis and the question of

belonging. Journal of Eastern African Studies, 12(3), 494-513.

Scott, J. C. (1998). Seeing like a state: How certain schemes to improve the human condition have failed. New Haven: Yale University Press.

Sheikh, S.A. (2007). Blood on the runway: the Wagalla massacre of 1984. Nairobi, Northern Publishing House.

Shiundu, A. (2015).Give us list of Al Shabaab sympathisers or quit, Kenyan MPs tell AdenDuale.TheStandard,https://www.standardmedia.co.ke/article/2000158684/give-us-list-of-al-shabaabsympathisers-or-quit-mps-tell-duale

Stanford University. (2016). Mapping military organisations: Al Shabaab.Retrieved from http://web.stanford.edu/group/mappingmilitants/cgi-bin/groups/view/61

Straus, S. (2015). Making and Unmaking Nations. War, Leadership, and Genocide in Modern Africa. Ithaca and London: Cornell University Press.

Van Selm, J. (2003). Refugee protection in Europe and the US after 9/11. In N. Steiner; M. Gibney and G. Loescher (Eds.), Problems of Protection: The UNHCR, Refugees, and Human Rights (pp.237-262). New York, NY: Routledge.

Whittaker, H. (2012). Forced villagization during the Shifta conflict in Kenya, ca. 1963-1968. International Journal of African Historical Studies, 45(3), 343-364. 